\title{
LEOSTHENES AND THE TRANSPORTATION OF GREEK MERCENARIES FROM ASIA MINOR
}

\author{
John Walsh
}

\begin{abstract}
Leosthenes is remembered for his heroic death at Lamia, but an earlier part of his career also deserves closer scrutiny. This paper analyzes Leosthenes' alleged role in transporting a number of mercenaries from Asia to Greece in the prelude to the Lamian war. A re-assessment of Leosthenes' actions suggests that his role in this event is grossly exaggerated and should be ascribed to the panegyrical elements that entered the historical tradition after his death. In addition, the thesis of O. Schmitt that Leosthenes transported the mercenaries from Asia on the orders of Alexander the Great has little to recommend it.
\end{abstract}

\section{Introduction}

Leosthenes' role in the preparations for the Lamian War ${ }^{1}$ remains consistently misunderstood. Because the major sources describing Leosthenes' participation in the Lamian War are not contemporary, but derivative, it is difficult to produce a historically accurate assessment of the much-admired general. ${ }^{2}$ Diodorus Siculus first mentions Leosthenes in his pre-emptive discussion of the causes of the outbreak of hostilities between Athens and Macedon. ${ }^{3}$ It is symptomatic of Diodorus' approach to writing history that exaggeration of Leosthenes' overall contribution to the preparation and management of the entire war should be freely intermingled with historical evidence. Diodorus was comfortable using his history as a vehicle for discussing broader issues of morality, by assigning blame and praise where he saw fit, and aggrandising or

\footnotetext{
1 For fundamental bibliography, see Seibert 1983: 92-97. See in general Schaeffer 1886; Stähelin 1924; Lepore 1955; Schmitt 1992; Habicht 1999; Blackwell 1999; Bosworth 2003. On the settlement at Babylon and affairs in Asia see most recently Meeus 2008. For the origin of the expression 'Lamian war,' see now Walsh 2011.

2 Diodorus is the most extensive surviving source for the period. See also Arrian, Succ. 1.9; Plut. Dem. 27; Phoc. 23-8; Hyp. Epi.; Justin 13.5; Paus. 1.25.3-5, 29.13; Strabo 9.5.10. See Hornblower 1981: 18-39. Modern scholarship has a low opinion of Diodorus' work. Niebuhr, Wesseling and Mommsen were especially scathing in their criticisms of him, and it is common for modern scholars to include apologies for the deficiencies of Diodorus in works which rely upon him as a source. See Bosworth 2003; Worthington 1984. For a more balanced discussion of Diodorus, see Hammond 1983: 12-79.

3 Diod. 17 111.1. This is a consistently misinterpreted passage. See Landucci 1984: 99: 'Ma già nel libro 17 Diodoro si era occupato della guerra lamiaca, presentandone le cause in modo diverso dal libro successivo ... .' Diodorus was not confused and did not assign two separate causes to the same event: the presence of Greek mercenaries and the repatriation of Greek exiles. See Diod. 18.8.1. Cf. Just. 12.5.1-17. Diodorus is

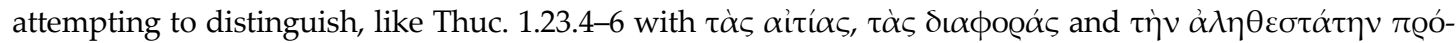

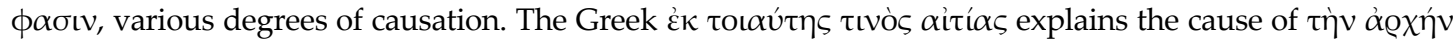

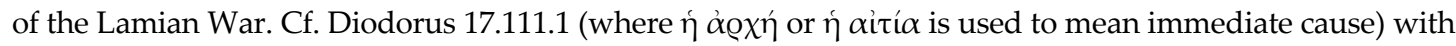
18.8.1 (where $\eta \dot{\alpha}$ iтí $\alpha$ alone indicates an underlying cause). For discussion of the mercenaries' role in the outbreak of the war, see Lepore 1955: 161.
} 
abbreviating as required. ${ }^{4}$ Where Diodorus took liberties in the interpretation of his own sources, blending the factual and allegorical, it is imperative for modern scholarship to rebalance the historical perspective we have of Leosthenes. While so doing, a broader contextual framework for understanding the Lamian War can be established. ${ }^{5}$ This paper analyzes Leosthenes' alleged role in transporting a number of mercenaries from Asia Minor to Greece in the prelude to the Lamian war. A re-assessment of Leosthenes' actions suggests that his role in this event is grossly exaggerated and should be ascribed to the panegyrical elements that entered the historical tradition after his death. In addition, the thesis of O. Schmitt, that Leosthenes transported the mercenaries from Asia on the orders of Alexander the Great, has little to recommend it.

In 324-323 BC, Leosthenes was supposedly involved in a major operation in the assembling of the mercenaries at Taenarum. ${ }^{6}$ Leosthenes has long been credited with the successful preparation and acquisition of a large mercenary force in southern Greece, but on careful analysis this view appears mistaken. The idea is largely based on a passage in Pausanias. ${ }^{7}$ According to Pausanias, Leosthenes had brought 50,000 mercenaries by ship to Greece from Asia after the Mercenaries decree, contrary to Alexander's wishes (Paus. 1.25.5; 8.52.5). Although Pausanias' numbers are certainly exaggerated, his evidence is often pressed into service to demonstrate that Leosthenes played an active role in shipping the mercenaries from the East, probably as an agent of Athens, which was now, in the last years of the reign, hostile to Alexander.

Recently O. Schmitt has presented the radical thesis that Leosthenes was involved in the transport of the mercenaries from Asia, but acting on the orders of Alexander himself, and as part of the king's plans to intimidate Athens:

4 Diod. 1.1.4: 'for it is an excellent thing to be able to use the ignorant mistakes of others as warning examples for the correction of error, and, when we confront the varied vicissitudes of life, instead of having to investigate what is being done now, to be able to imitate the successes which have been achieved in the past.' Though Diodorus was highly regarded by early Christian writers for his style of history (see Hornblower 1981: 18), his didactic aspirations corrupted the integrity and purely historical value of the work. See Wiseman 1993.

5 For discussion of Athenian suspicions regarding the legitimacy of early 'success' against Antipater and the wisdom of initiating the war, see Martin 2005. See also Plut. Phoc. 23.2 for Phocion's criticism of Leosthenes, and Plut. Tim. 6.5 for the suggestion that Leosthenes' achievements in the field were largely

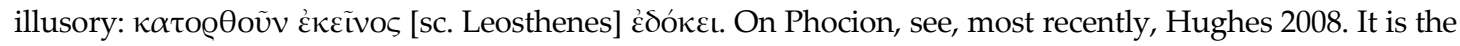
aim of this thesis to shift the scholarly emphasis back to this contemporary opinion. The reaction of Demosthenes to Harpalus' presence at Athens demonstrates he was concerned that the Athenians were not prepared to go to war. This suggests that Leosthenes' preparations are exaggerated in the sources. See Ashton 1983: 50.

6 Badian 1961: 27 dated the return of the mercenaries from Asia to early 324 BC. For background on the Lamian War, see Seibert 1983: 92-98; Lepore 1955; Gehrke 1976: 77-87; Will 1983; Habicht 1999: 36-41. On Leosthenes, see Geyer 1925; Berve 1926: 236-237; Kirchner 1966: 9142, 9144; Davies 1971: 342-344; Heckel 2006: 85; Sordi 2002: 463-76.

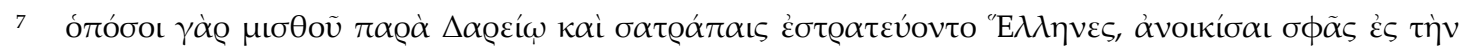

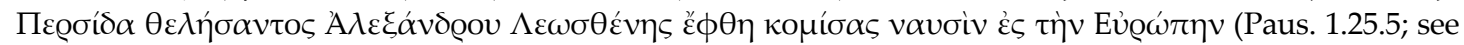
also 8.52.5). His exaggerated account distorts the situation and creates the false impression that Leosthenes repatriated the mercenaries against the will of Alexander, even somehow outwitting him. See, for instance, $C A H^{2}$ 6. 838: 'A considerable number followed the Athenian Leosthenes, who led them from Asia to the great mercenary depot at Taenarum in Laconia.' Cf. Diod. 17.106.2. For discussion of Leosthenes' apparent success as a mercenary commander, see Trundle 2004: 138. 


\begin{abstract}
'Was nun seine Rolle bei der Verschiffung der Söldner nach dem Tainaron anging, liegt es nahe, daß er von Alexander selbst damit beauftragt wurde. Für diese Aufgabe wird ihn die ererbte Gastfreundschaft und höchstwahrscheinlich eine in der Vergangenheit bewiesene Qualifikation empfohlen haben .... Gut möglich ist, daß der Transport mit Hilfe athenischer Schiffe durchgeführt wurde, die dem direkten Befehl des Leosthenes unterstanden. Sicher scheint, daß Leosthenes die Söldner in den Häfen Kilikiens oder Westkleinasien an Bord nahm und dann auf dem Tainaron ausschiffte, ausgemusterte Söldner wurden vielleicht auch auf Euboia, in Athen selbst oder in einer anderen griechischen Hafenstadt an Land gesetzt.'
\end{abstract}

'With regard to what Leosthenes' role was in the shipping of the mercenaries to Taenarum, one idea suggests itself: Leosthenes was engaged by Alexander himself. Alexander's inherited guestfriendship [with Leosthenes] and in all probability the latter's proven capability in the past will have recommended him for the task ... It is quite possible that the transportation was accomplished with the help of Athenian ships, which were under the direct command of Leosthenes. It seems certain that Leosthenes took the mercenaries on board in the harbours of Cilicia or on the west of Asia Minor and then disembarked at Taenarum, and perhaps discarded some mercenaries who were left on Euboea, in Athens itself or in another Greek port.' ${ }^{\prime 8}$

This thesis deserves critical scrutiny, as, in turn, does Leosthenes' own role in the shipping of the mercenaries.

Leosthenes' background is, of course, central to this debate. Leosthenes is usually identified as the son of that Leosthenes who had suffered exile in 362/1 BC (Diod. 15.95; Polyaen. 6.2.1-2), and who had fled to the court of Philip II. It is possible that Leosthenes, the later general, also spent time at the Macedonian court, but the details of his career before $324 \mathrm{BC}$ remain largely unknown.

Tarn suggested that Leosthenes was a mercenary commander under Alexander in Asia, and this has been followed by a number of scholars. ${ }^{9}$ However, Leosthenes' intense hostility to Alexander seems to militate against this view (Diod. 17.111.3), even though Diodorus, in the latter passage, does imply that Leosthenes had previously been a mercenary leader himself. An alternative view is that he was actually a mercenary commander in the service of Darius. ${ }^{10}$ Whatever the truth, it would appear that Leosthenes was in Athens and serving as trierarch in the years before Alexander's death. ${ }^{11}$ In turn, Worthington has concluded that Leosthenes held the position of trierarch in $325 / 4$ or possibly before that year. ${ }^{12}$ There is further epigraphic evidence sup-

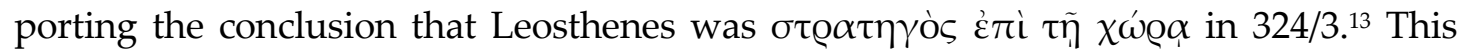
view, however, has been rejected by S. Jaschinski and A. B. Bosworth, on the grounds

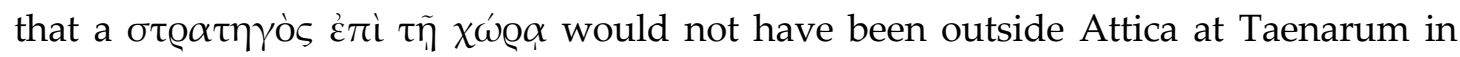

\footnotetext{
8 Schmitt 1992: 21-22. See also Marinovič 1989: 104: 'Cette nouvelle s'inscrit biens dans le tableau général, et le rôle conducteur de Léosthénés dans l'opération de transfert des anciens mercenaires grecs en Grèce est très probable.'

9 Tarn 1969: 455; C. R. Cooper in Worthington, Cooper \& Harris 2001: 128; Tritle 2009: 130.

10 See Badian 1961: 27; Milns 1968: 241, and Lane Fox 1973: 453. Will 1984: 30 agreed that Leosthenes had been a condottiere, but was undecided on the question whether he served Darius or Alexander. Cf. Hammond 1983: 107, who takes the view that Leosthenes was merely an 'Athenian mercenary commander ... [who] raised a fleet and shipped ... [sc. the Greek mercenaries] over to the Greek mainland. Entering into secret negotiations with Athens, Leosthenes kept a large number of mercenaries in readiness for action at Taenarum in the Peloponnese.'

11 IG II ${ }^{2}$ 1631. See Heckel 2006: 85.

12 Worthington 1987: 491.

13 Reinmuth 1971: 58-82, no. 15; Develin 1989: 408. Cf. Worthington 1987: 490. It is certain that Leosthenes was hoplite general in 323/2. See Habicht 1999: 35.
} 
324/3, and that Diodorus 18.9.2 suggests that the boule dealt with Leosthenes as a private individual when he was assembling the mercenaries, not as a public general. ${ }^{14}$ Diodorus 18.9.2 does seem to support the interpretation that Leosthenes was not an Athenian general around June 323 when he was ordered by the boule to enrol the mercenaries. $^{15}$

However, there is a possible solution to this problem of dating Leosthenes' generalship. S. V. Tracy has now re-dated Reinmuth's inscription to $329 / 8$ BC. ${ }^{16}$ On this view,

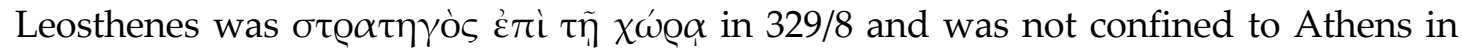
$324 / 3$, but was free to assemble the mercenaries at Taenarum. It is clear that if Leosthenes had been involved in the transport of the mercenaries from Asia, then this would have occurred between April/May to October, $324 .{ }^{17}$ If Leosthenes was elected to the office of general for 324/3, this activity may well have been confined to the period before midsummer when he would have assumed his office. ${ }^{18}$ If, however, Tracy's re-dating of Reinmuth's inscription to 329/8 BC is correct, then Leosthenes would have been free to continue the shipping through 324.

Alexander had issued his Mercenaries decree in Carmania in late 325, so the movement of mercenaries was well underway by early $324 .{ }^{19}$ On Schmitt's view, Alexander's plan was to transport mercenaries to Greece to counter any potential insurrection there or to intimidate Athens. Athens was now hostile to Alexander because the king wanted to return the Samian exiles to their homeland. Alexander's intention to restore the Samian exiles had been announced at Susa in 324 BC along with the Exiles' Decree. ${ }^{20}$

But Schmitt's theory faces two serious problems. First, if Leosthenes was a known public figure in his polis in 324, Alexander's appointment of an Athenian to oversee the build-up of mercenaries in Taenarum for potential use against Athens itself was an inexplicably imprudent policy. ${ }^{21}$ Furthermore, given the feeling against Alexander in the

14 Jaschinski 1981: 51-54, and Bosworth 1988: 293-94. See also Rhodes 2006: 343, who believes that the Leosthenes of the Ephebic Inscription is not the general of the Lamian War.

15 Alexander the Great died on 11 June, 323 BC and the archonship of Cephisodorus began on July 12, 323 BC (Meritt 1961: 133). Heisserer 1980: 188-89 dates the negotiations described in Diodorus 17.111.1-4 to the archonship of Anticles in 325/4 BC.

16 Tracy 1995: 25-26. Gomme 1933: 67-69 had already questioned the conventional dating. See also Gehrke 1976: 78, n. 12 and Bosworth 1988: 294. Thus Leosthenes must have returned to Athens before 329

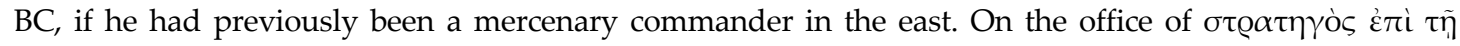

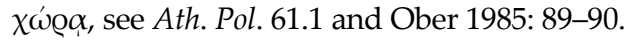

17 The sailing season was normally restricted to late spring to early autumn. See Morton 2001: 255-65. Moreover, ancient ships could cover around 100 to 150 nautical miles a day with favourable winds, and about half this with the wind against them (Casson 1971: 292-96). On navigation during antiquity see also Bilić 2009.

18 The election of Athenian generals was held after the sixth prytany (Ath. Pol. 44.4), that is, in February or March; they took up office later at the beginning of the year in midsummer (June or July). Meritt 1961: 133 has calculated that the archonship of Anticles (Diod. 17.110.1; 325/4) ended on July 22, 324 BC. Thus Leosthenes would have taken up his generalship after this date, if he did in fact hold one in 324/3.

19 Diod. 17.106.2. Bosworth 1988: 148-49. It is clear that Leosthenes' negotiations with the mercenaries and his selection as their leader occurred after their return from Asia, probably around the winter of 324/3 or sometime after this (Diod. 17.111.3; Miller 1982: 102, n. 17).

20 Badian 1961: 30, n. 96; Worthington 1986: 63, 65; Habicht 1999: 31. On Samos and the exiles see Schweigert 1940; Habicht 1957; Habicht 1975; Errington 1975; Rosen 1978; Shipley 1987; Hammond 1993; Habicht 1996; Schmitt 1996; Zahrnt 2003; Zahrnt 2004. On the chronology of the Exiles' Decree and the issue of the Samian exiles in particular, see Dmitriev 2005: 92, n. 160.

21 Blackwell 1999. 
city and the fact that one of the reasons the mercenaries were being ferried to Greece was to force the issue of the Samian exiles it is unlikely that the anti-Macedonian faction at Athens would have allowed the government to provide ships for such a transport. Alexander had previously requested ships from Athens, but had been vehemently opposed by the anti-Macedonian orators (Plut. Phoc. 21.1; Plut. Mor. 848e). Demosthenes, for instance, had opposed sending ships to Alexander precisely because the ships could have been used against Athens itself (Plut. Mor. 847c). By the autumn of 324, relations between Athens and Alexander had deteriorated to such an extent that at court Gorgos of Iasus was urging Alexander to attack Athens. ${ }^{22}$

Secondly, Pausanias' account seems to contradict Diodorus 17.111.1-4. Here, there is no explicit reference to the transport of the mercenaries by Leosthenes. Rather, the opposite is true. From Diodorus' narrative, it is clear that Leosthenes did not directly organise the transportation and assembly of the mercenaries dismissed by the Asian satraps as part of any great plan. ${ }^{23}$ The passages describing mercenaries, found split between Books 17 and 18 of Diodorus, when arranged to form a continuous narrative, establish that Leosthenes played no part in bringing these men to Taenarum:

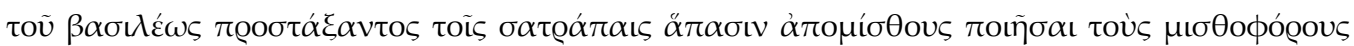

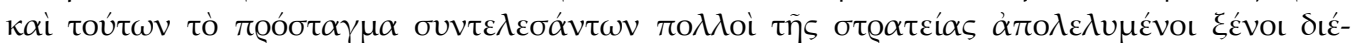

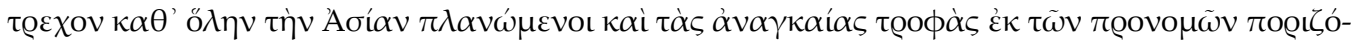

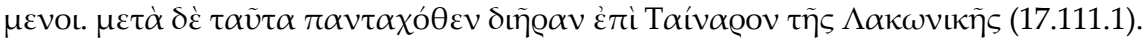

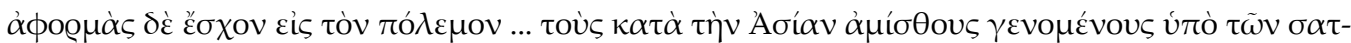

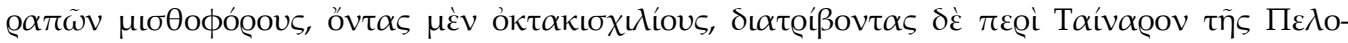
тоทขท́бov (18.9.1).

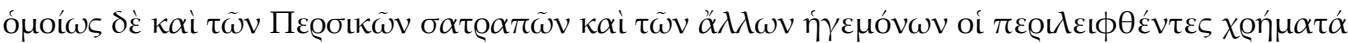

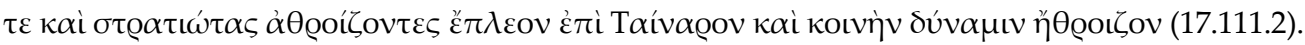

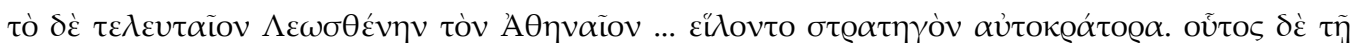

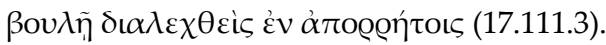

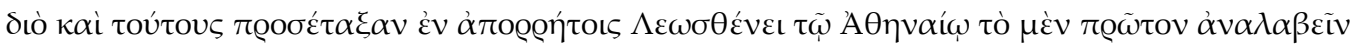

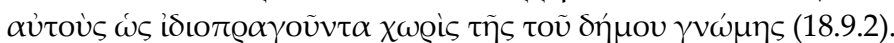

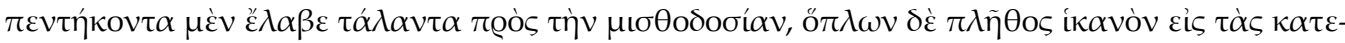

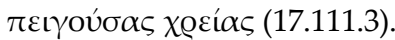

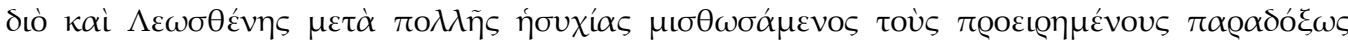

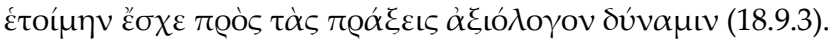

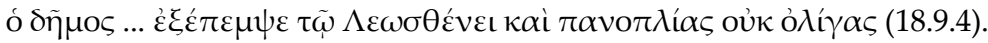

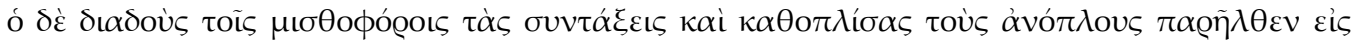
Ait $\omega \lambda i ́ \alpha v(18.9 .5)$.

22 Ephippus of Olynthus, FGrH 126, F5.

23 Diod. 17.111.1-4. There is no explicit mention here that Leosthenes was responsible for repatriating the mercenaries to Greece. The opposite is true. They began gathering at Taenarum from all directions them-

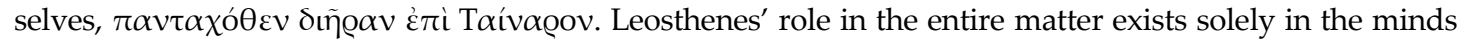
of panegyrists like Pausanias. Taenarum was an established and thriving mercenary marketplace in the fourth century and the logical place for these unemployed mercenaries to gather of their own accord and to seek employment (see Diod. 18.21.1-2). For a chronological analysis of Leosthenes' negotiations with the mercenaries at Taenarum and the similar 'problem' of the Aetolian alliance as described in Diodorus, see Mitchel 1964. 
We can analyze Leosthenes' purported military miracle at Taenarum by an examination of the evidence of these passages. The mercenaries were wandering throughout

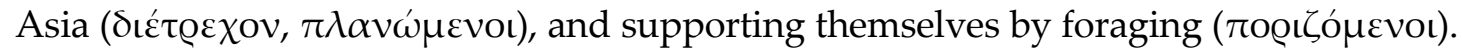
The text does not support the conclusion that they received any support from Leosthe-

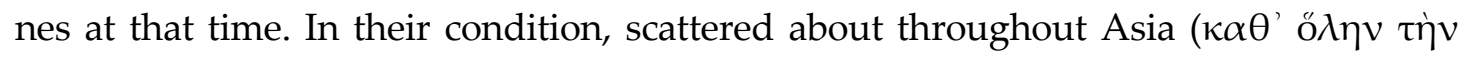
Aбí $\alpha v$ ), they would certainly have been beyond the reach or influence of Leosthenes. There existed, at this time, no unified body of mercenaries to repatriate to Greece. What would later become Leosthenes' mercenary army consisted of, for the moment, small self-supporting bands of mercenaries widely spread about Asia. Diodorus was

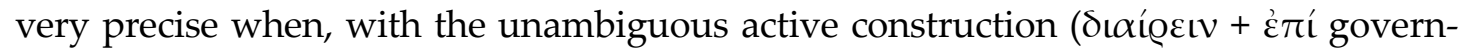
ing the accusative), ${ }^{24}$ he explained that the mercenaries crossed to Taenarum them-

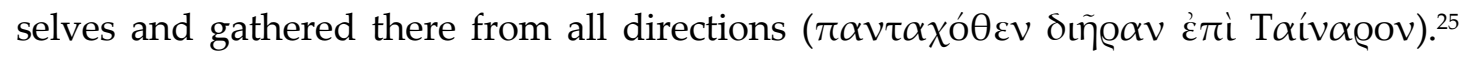
Leosthenes' role in their transport may well have been grossly exaggerated by Pausanias or the panegyrical sources he used. Taenarum was an established and thriving mercenary marketplace in the fourth century and the logical place for these unemployed mercenaries to gather of their own accord to seek employment. ${ }^{26}$

Upon their arrival in Greece, the mercenaries' condition does not suggest that they had been evacuated purposefully from Asia. They were for the moment directionless

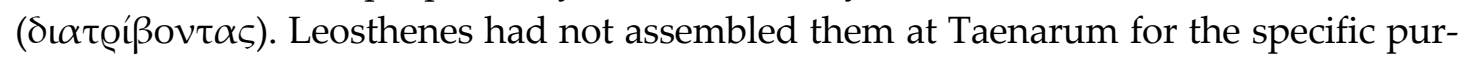
pose of fighting a war. Surely, had a grand evacuation from Asia occurred, Leosthenes would have made some arrangements for the mercenaries when they arrived in Greece. At this point, the narrative provides no evidence linking the mercenaries to Leosthenes any more than to the Athenian moneymen who would eventually fund their service. Control and financial support of individual groups of mercenaries remained amongst the surviving satraps and generals who accompanied them to Taena-

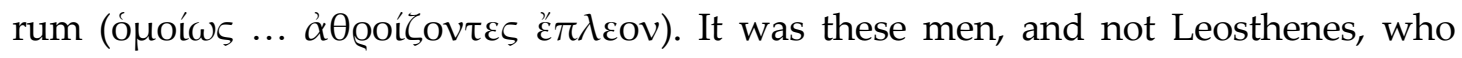

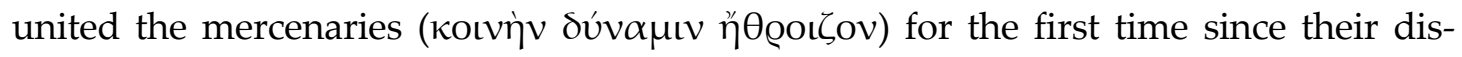
persal throughout Asia. The mercenaries gathered at Taenarum in groups, some maintained by their satraps and Persian commanders, others obviously sustaining themselves. ${ }^{27}$ To conclude that Leosthenes played a significant role at Taenarum requires that we ignore the best available literary evidence in Diodorus, in favour of Pausanias' presumptive reasoning. ${ }^{28}$

What, then, was Leosthenes' role in the shipping of the mercenaries? It is widely accepted that Pausanias' figure of 50,000 is greatly exaggerated. ${ }^{29}$ Harpalus, for instance, who made off with the staggering sum of 5,000 talents of silver, could only organise the transport of a force of 6,000 mercenaries (Diod. 17.108.6) with a fleet of

24 Diod. 17.111.1; 19.70.6, 71.5, 79.4; 20.37.2. This seems to be a later feature of Diodorus' writing and possibly more representative of his source than of himself. It is a construction confined to describing sea voyages. When he describes the transportation of military forces by a commander, Diodorus employed the term $\delta\llcorner\alpha \beta \iota \beta \alpha ́ \zeta \varepsilon เ v$. See, for example, Diod. 18.63.6.

25 Diod. 17.111.1-2.

26 See Trundle 2004: 112. For a chronological analysis of Leosthenes' negotiations with the mercenaries at Taenarum and the similar 'problem' of the Aetolian alliance as described in Diodorus, see Mitchel 1964.

27 Diod. 18.9.4-5. For the Athenian supply of armour to the mercenaries, see Diod. 18.9.4 and Bertosa 2003.

28 The obvious difficulty of reconciling Pausanias' remarks with the other evidence has caused scholarly confusion: see Badian 1961: 16-43.

29 Badian 1961: 27, n. 78. 
thirty ships (Curtius 10.2.1). Using this figure as a guide, we can estimate that Leosthenes would have required two hundred and fifty ship-loads of men: Leosthenes, therefore, would have required access to a number of ships and rowers that exceeded the service capacity of the Athenian navy itself. ${ }^{30}$ We would also have to dismiss other examples of such events in ancient history and ignore Xenophon's Anabasis to believe that large-scale military evacuations and transports were undertaken with such apparent ease. ${ }^{31}$

Moreover, in the summer of $324 \mathrm{BC}$, the Athenians are known to have had only 40 ships at sea. ${ }^{32}$ Thus, even if we assume that all of these ships at sea in 324 were involved in the transport of mercenaries to Greece under Leosthenes (and they certainly were not), they could have transported at most around 8,000 mercenaries. If we assume that half the number were available, then a figure of 4,000 is possible.

But it is far more likely that the mercenaries had gathered at Taenarum in ragged groups and had found transport without the aid of a large number of Athenian ships. Some might have been maintained by their satraps and Persian commanders, while others obviously sustained themselves. We know that Athens supplied arms and armour for some of the mercenaries later. Most probably, some of the men required new arms because they sold their equipment to fund their passage, or did not have the resources to pay for new equipment; others may not have had the space to ship their arms when they sailed from Asia. The mixed condition and fortunes of the men suggests that they did not share a common experience of evacuation from Asia on ships organised by Leosthenes. Rather, the mercenaries' condition is consistent with the view that they were a collection of smaller individual refugee groups. The difficulties in funding, and the logistical problems associated with moving, large numbers of men by sea from Asia to Greece at short notice make it virtually impossible that Leosthenes was responsible for the mercenary build-up at Taenarum in the way that Pausanias describes or in the manner normally imagined by modern scholars. ${ }^{33}$

It is clear that the mercenaries eventually chose Leosthenes as their commander

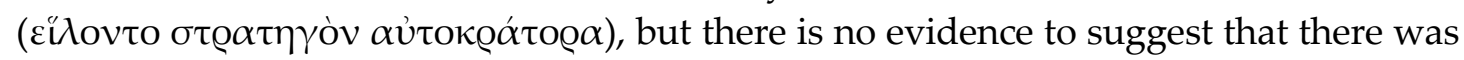
anything remarkable about this. In fact, it is reference to this specific event that forces the conclusion that Leosthenes was not in a position of leadership before this time. He was chosen to command a force that had been unified by the officers with which it arrived, but before his involvement. Although Diodorus and Pausanias were convinced

\footnotetext{
30 For the condition of the Athenian navy at this time, see Morrison 1987; Sekunda 1992; Ashton 1977; Bosworth 2003: 14-22.

31 Diod. 18.63.6; cf. 18.73.2; with Anson 2004: 157-58. Eumenes' transportation of troops to Asia against Antigonus in $318 \mathrm{BC}$ demonstrates the planning required for such an operation and its complexity. Harpalus, who made off with the staggering sum of 5000 talents of silver, could only organise the transport of 6000 mercenaries. See Diod. 17.108.6. Harpalus had a fleet of thirty ships for 6000 mercenaries. See also Curtius 10.2.1.

32 IG II ${ }^{2}$ 1629.783-812. See Bosworth 2003: 15.

33 Cf. Worthington (1987: 491): 'What ... [sc. Pausanias] meant ... when he said that 50,000 mercenaries were 'brought over 'from Persia to Greece by Leosthenes ... is not that the latter provided the ferries himself or led them across, but that he was responsible for arranging their passage. Possibly some, if not all, of the funding was provided by those satraps and leading officers also en route to Taenarum; they would certainly have had the means to do so.' At most, if Leosthenes had been a trierarch in 325/4, then it is likely that he had some limited role in persuading the Persian satraps and their leaders to take their mercenaries to Taenarum, where they could expect employment in the future from Athens in the event of war.
} 
that his interaction with the mercenaries concealed the brilliant handiwork of Leosthenes, the weight of evidence does not support their expansive, rhetorical conclusions. Unable to identify a legitimate accomplishment, Diodorus did not hesitate to use his license to exaggerate. Leosthenes, he concluded rather arbitrarily, was elected leader of the mercenaries on the basis of his peculiarly brilliant mind. ${ }^{34}$ Diodorus was a moralist and it befitted the noble nature of the Athenian uprising that its leader be equally

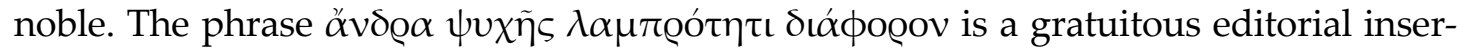
tion by Diodorus, a stock characterisation that he employed with some regularity. Diodorus' other uses of this description link the idea of a brilliant mind with some other virtuous or heroic attribute. ${ }^{35}$ This particular use, abrupt and unnatural as it is, both in the literary and critical sense, reflects the underlying inappropriateness of the comparison. There is a forced and inorganic feel to the statement that suggests Diodorus struggled to find anything praiseworthy about the affair. ${ }^{36}$ It is probable that Diodorus drew on his stock of moral comparisons to retroactively lend Leosthenes' election a degree of brilliance it did not deserve. ${ }^{37}$

The image of a wandering band of mercenary ideologues following a brilliant leader on a noble quest for freedom makes for effective literature, but is historically unrealistic. What is a much more reasonable scenario is that the prospect of a wellfinanced Athenian paymaster would attract the mercenaries' temporary interest and loyalty, irrespective of the quality of their employer's mind. Pausanias and Diodorus have obviously embellished this earlier event in Leosthenes' career, and the panegyrical apotheosis of Leosthenes had already been set by Hypereides' funeral oration, delivered after the general's death. ${ }^{38}$ But the historical reality is that unemployed mercenaries come into the employment of a well-financed employer at an established mercenary recruiting centre ${ }^{39}$ Accepting the leadership of a mercenary army assembled by its own officers and paid for by Athens, Leosthenes' role in the affair was exaggerated, whether his own later military and strategic skill was mediocre or outstanding.

\footnotetext{
34 Diod. 17.111.3.

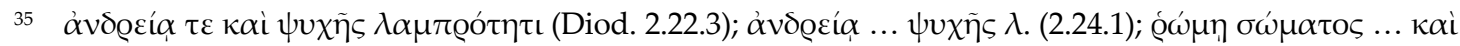

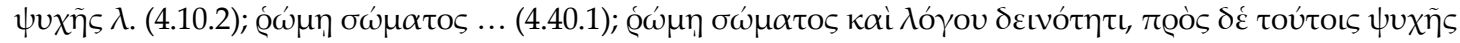

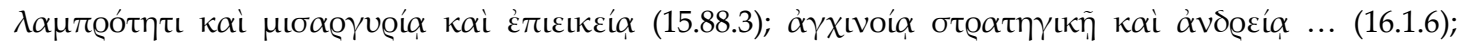

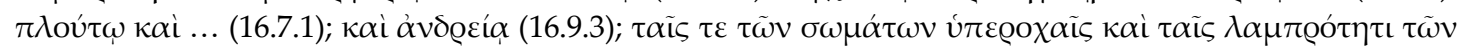
$\psi v \chi \tilde{\omega} v$ (17.59.3). See also 16.9.3 for use as a subject and 16.6.1, 6.4 for $\delta \dot{\alpha} \alpha$ plus the accusative construction. The process by which a myth was constructed can be seen when Pausanias later borrows the same term when further exaggerating Leosthenes' involvement in the matter. See Paus. 1.25.5.

36 This is an awkward and unusual pairing of characteristics, mental brilliance and political opposition to

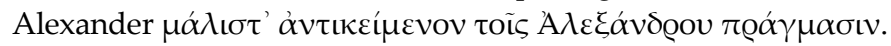

37 Leosthenes does not deserve to be included in this list of luminaries (viz., Memnon, Medus, Herakles, Jason, Epameinondas, Philip, Andromachus, Dion, and the Persian royal guards). He is notably absent from the modern Greek cultural lexicon of nationalist heroes.

38 Herrman 2009.

39 Cf. Diod. 17.108.7. When Harpalus fled Asia upon Alexander's return from India (326/5 BC), there was no gratuitous reference to his brilliant mind when he hired a mercenary army. He was regarded as a villain and it did not suit Diodorus' purpose to project commendable qualities upon him. That he left his army at Taenarum, presumably at their request, when he was turned away from Attica further emphasises that this was the most likely destination for unemployed mercenaries at the time.
} 
John Walsh, PhD

School of Languages and Literatures, University of Guelph

Guelph, ON N1G 2W1 Canada

E-mail:waljo@uoguelph.ca

\section{BIBLIOGRAPHY}

Anson, E. M. (2004) Eumenes of Cardia: A Greek Among Macedonians. Boston: Brill.

Ashton, N. G. (1977) 'The Naumachia near Amorgos in 322 B.C.' - BSA 72, 1-11.

Ashton, N. G. (1983) 'The Lamian War - A False Start?' - Antichthon 17, 47-63.

Badian, E. (1961) 'Harpalus.' - JHS 81, 16-43.

Bertosa, B. (2003) 'The Supply of Hoplite Equipment by the Athenian State Down to the Lamian War.' - Journal of Military History 67.2, 361-79.

Berve, H. (1926) Das Alexanderreich auf Prosopographischer Grundlage (vol. 2). München: Beck.

Bilić, T. (2009) 'The Myth of Alpheus and Arethusa and Open-Sea Voyages on the Mediterranean-Stellar Navigation in Antiquity.' - IJNA 38.1, 116-120.

Blackwell, C. W. (1999) In the Absence of Alexander: Harpalus and the Failure of Macedonian Authority. (Lang Classical Studies; 12.) New York: Peter Lang.

Bosworth, A. B. (1988) Conquest and Empire. The Reign of Alexander the Great. Cambridge: Cambridge University Press.

Bosworth, A. B. (2003) 'Why did Athens lose the Lamian War?' - Palagia, O.; Tracy, S. V. (eds.), The Macedonians in Athens 322-229 B.C. Oxford: Oxbow, 14-22.

Casson, L. (1971) Ships and Seamanship in the Ancient World. Princeton, N.J.: Princeton University Press.

Davies, J. K. (1971) Athenian Propertied Families. Oxford: Clarendon Press.

Develin, R. (1989) Athenian Officials, 684-321 B.C. Cambridge; New York: Cambridge University Press.

Dmitriev, S. (2005) City Government in Hellenistic and Roman Asia Minor. Oxford; New York: Oxford University Press.

Errington, R. M. (1975) 'Samos and the Lamian war.' - Chiron 5, 51-57.

Gehrke, H.-J. (1976) Phokion: Studien zur Erfassung seiner historischen Gestalt. (Zetemata; 64.) München: Beck.

Geyer, F. (1925) 'Leosthenes (2).' - RE 12.2, 2060-2062.

Gomme, A. W. (1933) The Population of Athens in the Fifth and Fourth centuries B.C. Oxford: Blackwell.

Habicht, C. (1957) 'Samische Volksbeschlüsse der hellenistischer Zeit.' - MDAI(A) 72, 152-274.

Habicht, C. (1975) ‘Der Beitrag Spartas zur Restitution von Samos während Lamischen Krieges.' - Chiron 5, 45-50.

Habicht, C. (1996) 'Athens, Samos, and Alexander the Great.' - PAPhS 140.3, 397-403.

Habicht, C. (1999) Athens from Alexander to Antony (trans. D. L. Schneider). Cambridge, Mass. and London: Harvard University Press.

Hammond, N. G. L. (1983) Three Historians of Alexander the Great: the so-called Vulgate authors, Diodorus, Justin, Curtius. Cambridge: Cambridge University Press. 
Hammond, N. G. L. (1993) 'Alexander's letter concerning Samos in Plut. Alex. 28, 2.' Historia 42.3, 379-382.

Hammond, N. G. L.; Walbank, F. W. (1988) A History of Macedonia, Volume III, 336-167 B.C. Oxford: Clarendon Press.

Heckel, W. (2006) Who's Who in the Age of Alexander the Great: Prosopography of Alexander's Empire. Malden, Mass.: Blackwell.

Heisserer, A. J. (1980) Alexander the Great and the Greeks: The Epigraphic Evidence. Norman: University of Oklahoma Press.

Herrman, J. (2009) Hyperides: Funeral Oration. Oxford: Oxford University Press.

Hornblower, J. (1981) Hieronymus of Cardia. Oxford: Oxford University Press.

Hughes, S. (2008) After the Democracy: Athens under Phocion (322/1-319/8 B.C.). Diss. University of Western Australia.

Jaschinski, S. (1981) Alexander und Griechenland unter dem Eindruck der Flucht des Harpalos. Bonn: Habelt.

Kirchner, J. (1966) Prosopographia Attica. Berlin: de Gruyter.

Landucci, F. (1984) 'La morte di Alessandro e la tradizione su Antipatro.' - Sordi, M. (ed.), Alessandro Magno tra storia e mito. Milano: Jaca Book, 91-111.

Lane Fox, R. (1973) Alexander the Great. London: Allen Lane.

Lepore, E. (1955) 'Leostene e le origini della guerra lamiaca.' - PP 10, 161-185.

Marinovič, L. P. (1989) 'Les mercenaires de la guerre lamiaque.' - DHA 15.2, 97-105.

Martin, G. (2005) 'Antipater after the Lamian War: New Readings in Vat. Gr. 73 (Dexippus Fr.33).' - CQ 55, 301-305.

Meeus, A. (2008) 'The Power Struggle of the Diadochoi in Babylon, 323 B.C.' - AncSoc 38, 39-82.

Meritt, B. D. (1961) The Athenian Year. (Sather Classical Lectures; 32.) Berkeley: University of California.

Miller, S. G. (1982) 'Kleonai, the Nemean Games, and the Lamian War.' - Studies in Athenian Architecture, Sculpture and Topography. Presented to Homer A. Thompson. (Hesperia Supplements; 20.) Princeton, New Jersey: American School of Classical Studies at Athens, 100-108.

Milns, R. D. (1968) Alexander the Great. New York: Pegasus.

Mitchel, F. W. (1964) 'A Note on IG II² 370.' - Phoenix 18.1, 13-17.

Morrison, S. (1987) 'Athenian Sea-Power in 323/322 BC: Dream and Reality.' - JHS 107, 88-97.

Morton, J. (2001) The Role of the Physical Environment in Ancient Greek Seafaring. (Mnemosyne: Supplementa; 213.) Leiden; Boston: Brill.

Ober, J. (1985) Fortress Attica: Defense of the Athenian Land Frontier, 404-322 B.C. (Mnemosyne: Supplementa; 84 .) Leiden: Brill.

Reinmuth, O. W. (1971) The Ephebic Inscriptions of the Fourth Century B.C. (Mnemosyne: Supplementa; 14.) Leiden: Brill.

Rhodes, P. J. (2006) A History of the Classical Greek World, 478-323 B.C. Oxford, UK; Malden, Mass.: Blackwell.

Rosen, K. (1978) 'Der göttliche Alexander, Athen und Samos.' - Historia 27, 20-39.

Schaeffer, H. (1886) Der lamische oder hellenistiche Krieg nach den Quellen dargestellt. Diss. Giessen.

Schmitt, O. (1992) Der Lamische Krieg. Bonn: Habelt.

Schmitt, O. (1996) 'Deinarch, Hypereides und Samos.' - Klio 78.1, 61-67. 
Schweigert, E. (1940) ‘The Athenian cleruchy on Samos.' - AJPh 61.2, 194-198.

Seibert, J. (1983) Das Zeitalter der Diadochen. (Erträge der Forschung; 185) Darmstadt: Wissenschaftliche Buchgesellschaft.

Sekunda, N. V. (1992) 'Athenian Demography and Military Strength 338-322 B.C.' ABSA 87, 311-55.

Shipley, G. (1987) A History of Samos, 800-188 B.C. Oxford: Clarendon Press.

Sordi, M. (2002) Scritti di storia greca. Milano: V\&P Università.

Stähelin, F. (1924) ‘Lamischer Krieg.' - RE 12.1, 562-564.

Tarn, W. W. (1969) 'The Succession to Alexander.' - Bury, J. B.; Cook, S. A.; Adock, F. E. (eds), The Cambridge Ancient History. Volume VI, Macedon 401-301 BC. Cambridge: Cambridge University Press.

Tracy, S. V. (1995) Athenian Democracy in Transition. Attic Letter-Cutters of 340 to 290 B.C. (Hellenistic Culture and Society; 20.) Berkeley: University of California Press.

Tritle, L. A. (2009) 'Alexander and the Greeks: Artists and Soldiers, Friends and Enemies.' - Heckel, W.; Tritle, L. A. (eds), Alexander the Great: A New History. Chichester, U.K. and Malden, MA: Wiley-Blackwell, 121-140.

Trundle, M. (2004) Greek Mercenaries: From the Late Archaic Period to Alexander. London; New York: Routledge.

Walsh, J. (2011) 'The Lamiaka of Choerilus of Iasos and the Genesis of the Term "Lamian War".' - CQ 61.2, 538-544.

Will, E. (1984) 'The Succession to Alexander.' - Walbank, F. W.; Astin, A. E.; Frederiksen, M. W.; Ogilvie, R. M. (eds.), The Cambridge Ancient History, Part 1, The Hellenistic World (2nd ed.). Cambridge: Cambridge University Press.

Will, W. (1983) Athen und Alexander: Untersuchungen zur Geschichte der Stadt von 338 bis 322 v. Chr. (Münchener Beiträge zur Papyrusforschung und antiken Rechtsgeschichte; 77.) München: Beck.

Wiseman, T. P. (1993) 'Lying Historians: Seven Types of Mendacity.' - Gill, C.; Wiseman, T. P. (eds.), Lies and Fiction in the Ancient World. Exeter: University of Exeter Press, 122-146.

Worthington, I. (1984) 'IG II² 370 and the Date of the Athenian Alliance with Aetolia.' ZPE 57, 139-144.

Worthington, I. (1986) 'The Chronology of the Harpalus Affair.' - Symbolae Osloenses 61, 63-76.

Worthington, I. (1987) 'The Earlier Career of Leosthenes and IG II.2 1631.' - Historia 36, 489-491.

Worthington, I.; Cooper, C. R.; Harris, E. M. (2001) Dinarchus, Hyperides, and Lycurgus. Austin: University of Texas Press.

Zahrnt, M. (2003) `Versöhnen oder Spalten? Überlegungen zu Alexanders Verbanntendekret.' - Hermes 131, 407-432.

Zahrnt, M. (2004) 'Ist Samos eine Messe wert?' - Kinsky, R. (ed.), Diorthoseis: Beiträge zur Geschichte des Hellenismus und zum Nachleben Alexanders des Grossen. (Beiträge zur Altertumskunde; 183.) München; Leipzig: Saur, 9-23. 